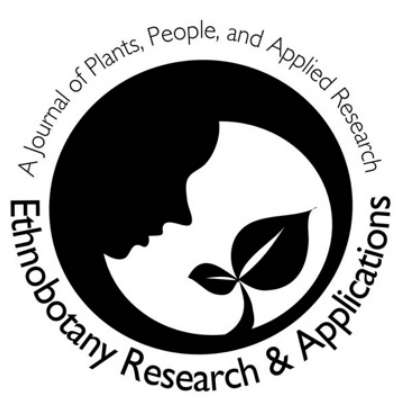

\section{Reviews and Mini reviews}

Background: Ethnobotany is the study of the plants used by aboriginal people. It has significant contributions in bioprospecting, drug development and management of natural resources and cultural diversity. Diversity of plants and tribes makes India an ideal place for ethnobotanical research. Therefore, mapping of scholarly publication was conducted on various scientometric indicators to identify the research trends on ethnobotany in India.

Methods: Data for this study were retrieved from Web of Science Core collection database of Clarivate analytics (erstwhile Thomson Reuters), Philadelphia, USA up to year 2018.

Results: The first research paper in $\mathrm{SCl}$ journal was published in 1974, and during 1974 to 2018, a total of 2123 papers have been published. The publication trends may be divided in between three phases: first phase was 22 years long (1974-1996) with yearly publications in single digit; second phase was for 10 years (1997- 2006) demarked by publications in double digits; third phase was initiated in 2007 producing yearly publications in three digits. These 2123 papers have been contributed by 5458 authors, affiliated to 1927 organizations. Of these, Council of Scientific \& Industrial Research (207 records, 3960 citations) is leading in the list of contributing organizations and $\mathrm{S}$. Ignacimuthu (30 records and 1,163 citations) is the most productive author. Analysis of international collaboration revealed that Indian researchers are in collaboration with 79 different countries among which USA (4.8\% papers) was major collaborating country. A total of 105 tribes of India have been studied and maximum records were available for Adi tribe (17 publications). The most preferred journal was Indian Journal of Traditional Knowledge and the top cited article was on antidiabetic plants published in Journal of Ethnopharmacology in 2002.
Conclusions: The ethnobotany research in India is increasing despite of emergence of new research areas and depletion of traditional knowledge. The present study will provide a platform for future studies and strengthening the ethnobotanical research in India.

Keywords: Bibliometrics, Ethnobotany, Scientific output, Research trends

\section{Correspondence}

\author{
Manohar Pathak ${ }^{1}$ and Kumar Avinash Bharati ${ }^{*}$ \\ ${ }^{1}$ Directorate of Education, GNCT, Delhi \\ ${ }^{2}$ Central National Herbarium, Botanical Survey of \\ India, Howrah- 711103, India
}

*Corresponding Author: k.avinash@hotmail.com

Ethnobotany Research \& Applications

20:49 (2020)

\section{Background}

Ethnobotany is the study of the plants used by aboriginal people (Harshberger 1896). The use of plants is a part of complex social-ecological system; it indicates how relationship between nature and human evolve in time and space (Albuquerque et al. 2017). This knowledge is essential for the survival of human beings therefore orally transmitting from generation to generation. Classical ethnobotanists document the ways in which ethnic people use the plants (Prance 1991). Since past few decades, ethnobotany has evolved as a multidisciplinary subject incorporating information from other subjects like, anthropology, chemistry, pharmacology, geography, ecology, environmental sciences, economics, linguistics, medicine, horticulture, etc. (Gaikward et al. 2011). 
Contributions of ethnobotany are significant in drug development, germ plasm conservation, crop improvement, selection of new plants for domestication, assessment of cultural position of tribes, study of the distribution of plants, new lines of manufacture, resource management, early identification of species in trade, etc (Farnsworth et al. 1985; Balick 1996; Henrich 2000). In absence of proper documentation, western pharmaceutical companies are stealing indigenous knowledge for commercial benefits. Further, traditional knowledge systems are rapidly fading away because biodiversity is depleting, tribes are vanishing, indigenous cultures and languages are disappearing. Convention on Biodiversity (1992) addresses the issues of vanishing and stealing of indigenous knowledge system and establishes international protocols; it binds signatory nations for the following: (a) preservation and maintenance of traditional knowledge; (b) application of traditional knowledge; (c) equitable sharing of benefits from traditional knowledge (Cox 2000; Barsh, 2001). Ethnobotany is vital for human beings, not only because its bioprospecting roles but also for management and maintenance of natural resources and cultural diversity.

India is the home of 705 tribes and rich in plant diversity having 18386 of angiosperms, 79 gymnosperms, 1289 pteridophytes, 2748 bryophytes, 2511 lichens, 15115 fungi and 7357 algae (Dash et al. 2018; https://tribal.nic.in/). The diversity of tribes and plant wealth make India a perfect place to study the ethnobotany. About 150 years back, British Government in India had realised the fact and utilized traditional knowledge in economic activities. Initiatives for documentation of folk knowledge was taken by Sir George Watt (1873), he explored remote areas and published "Dictionary of Economic products of India" in six volumes (Chakravarthy 1975). In 1925, Bodding had documented medicinal plants of Santhal tribes (Bodding 1925; 1927; 1940; 1983). The actual research on Ethnobotany in India was started by $\mathrm{Dr}$ S.K. Jain. He explored many tribal areas, and the first publication was appeared in 1963 (Jain 1963). After that many researchers are involved in research on ethnobotany and publications are coming every year (Shah 2008).

Therefore, bibliometric analysis of research on ethnobotany could serve as an alternative and innovative way of revealing research trends on ethnobotany in India. Also, it helps in assessing India's contribution to the global literature in ethnobotany. Such bibliometric studies have been published on Latin America (Albuquerque et al. 2013) and Brazil (Ritter et al. 2015; Hanazaki 2015).
In the Indian context, the first bibliometric study was on "Ethnobotany journal" by Dhiman (2000), thereafter, Dhiman \& Sinha (2001) investigated impact of collaboration in Ethnobotany in between 1989 to 1999. Different aspects of bibliometrics analysis on "Indian Journal of Traditional Knowledge" was published by Shivakumaraswmay \& Muthuraj (2015), Pathak \& Bharati (2018) and Kolle (2018). No previous mapping of ethnobotany research in India has been done to the best of our knowledge. Therefore, we have done a bibliometric analysis of ethnobotany research indexed in SCI-E contributed from India up to 2018. The following questions were addressed through the study: (i) What is the current status of ethnobotany research in India? (ii) What are the research trends in ethnobotany in India? (iii) How many tribes are studied so far? (iv) Which institute is actively involved in ethnobotany research (vi) Who is the most productive author? (vii) What are the collaboration patterns at national and international level?

The study was designated to test the following hypothesis: (i) ethnobotany research in India is declining due to emergence of new research areas in botany and depletion of traditional knowledge; (ii) ethnobotany research is restricted to small universities and institution because it requires comparatively less funds.

The specific objectives of the study were to: (i) map the ethnobotanical research in India; (ii) list research performance on multiple parameters, such as author, year wise citation patterns, document types, highly cited documents, leading institutions, document types, keywords, tribes, journals and collaborations.

\section{Materials and Methods}

Data for this study were retrieved from Web of Science Core collection database of Clarivate Analytics on 15th September 2019 by using keyword ETHNOBOTAN* OR Ethnovetr* OR Ethnomed* OR "traditional knowledge" OR "alternative medicine" OR "Herbal medicine" OR "Folk Medicine" in Topic field (https://clarivate.com/webofsciencegroup/). Results obtained were refined by India from list of countries and the literatures published after 2018 were excluded. Year wise citations were downloaded by using "create citation report" feature of the Web of Science. This yielded 2123 results and were downloaded in Excel format for further analysis. Impact factor of the journals were obtained from Journal citation report released in year 2019. There were different variants for authors and organization's name therefore records were manually checked to avoid anomaly and standardized the unique names. To find out unique author names, the affiliations were checked and reprint author e-mails, if available. Next 
level verification to ensure the correctness of the data, some original papers from publishers' website was also crosschecked to remove anomalies to the best possible level. Web of science does not classify research publications in "ethnobotany". Instead, most of the ethnobotany papers are classified either in the area Plant Sciences or Complementary and Integrative Medicine. Boolean operator 'OR' were used to separate the terms to include all possible synonymous terms used in ethnobotanical research in order to retrieve all available data in the database in ethnobotany. However, there are many Indian publications in ethnobotany which have been published in the journals not indexed in Web of Science viz. Ethnobotany, Journal of Economic and Taxonomic Botany, Nelumbo, Indian Forester, etc. Therefore, publications in such journals have not been considered for this study. Search strings are as under:

TOPIC $=\left(\right.$ ETHNOBOTAN ${ }^{*}$ OR Ethnovetr* OR Ethnomed* OR "traditional knowledge" OR "alternative medicine" OR "Herbal medicine" OR "Folk Medicine") Refined COUNTRIES/REGIONS= (INDIA) AND [excluding] PUBLICATION YEARS=(2019) Timespan=All years. Indexes=SCI-EXPANDED, SSCI, CPCl-S, CPClSSH, CCR-EXPANDED, IC. Software VoSviewer version 1.6.11 were used for co-authorship network, keyword network mapping and other visualisations.

\section{Results and Discussion}

Publication outputs and major journals

First research paper on ethnobotany in $\mathrm{SCl}$ journal was published in 1974. In between 1974 to 2018, a total of 2123 papers have been published on Indian ethnobotany. Of the total publications, $81.72 \%$ (1735) were appeared as articles, $10.64 \%$ (226) as reviews, $3.29 \%$ (70) as proceedings papers, $1.27 \%$ (27) as meeting abstracts, $1.03 \%(22)$ as editorial materials, $0.65 \%(14)$ as letters, $0.28 \%(6)$ as news items, $0.18 \%(4)$ as notes and $0.04 \%$ (1) as book review (Fig. 1). It has been observed that articles on ethnobotany possess inherent classification under six groups, i.e. (i) Ethnomedicine (745 articles), (ii) Ethnopharmacology (773 articles), (iii) Ethnoecology (42 articles), (iv) Ethnozoology (25 articles), (v) Ethnovetrinary (11 articles) and (vi) Others (139 articles). As depicted in Fig. 2, the publication trends may be divided in between three phases: first phase was 22 years (1974-1996) long with yearly publications in single digit; second phase was for 10 years (1997- 2006), it shows publications in double digits; third phase was initiated in 2007, produced publications in three digits.

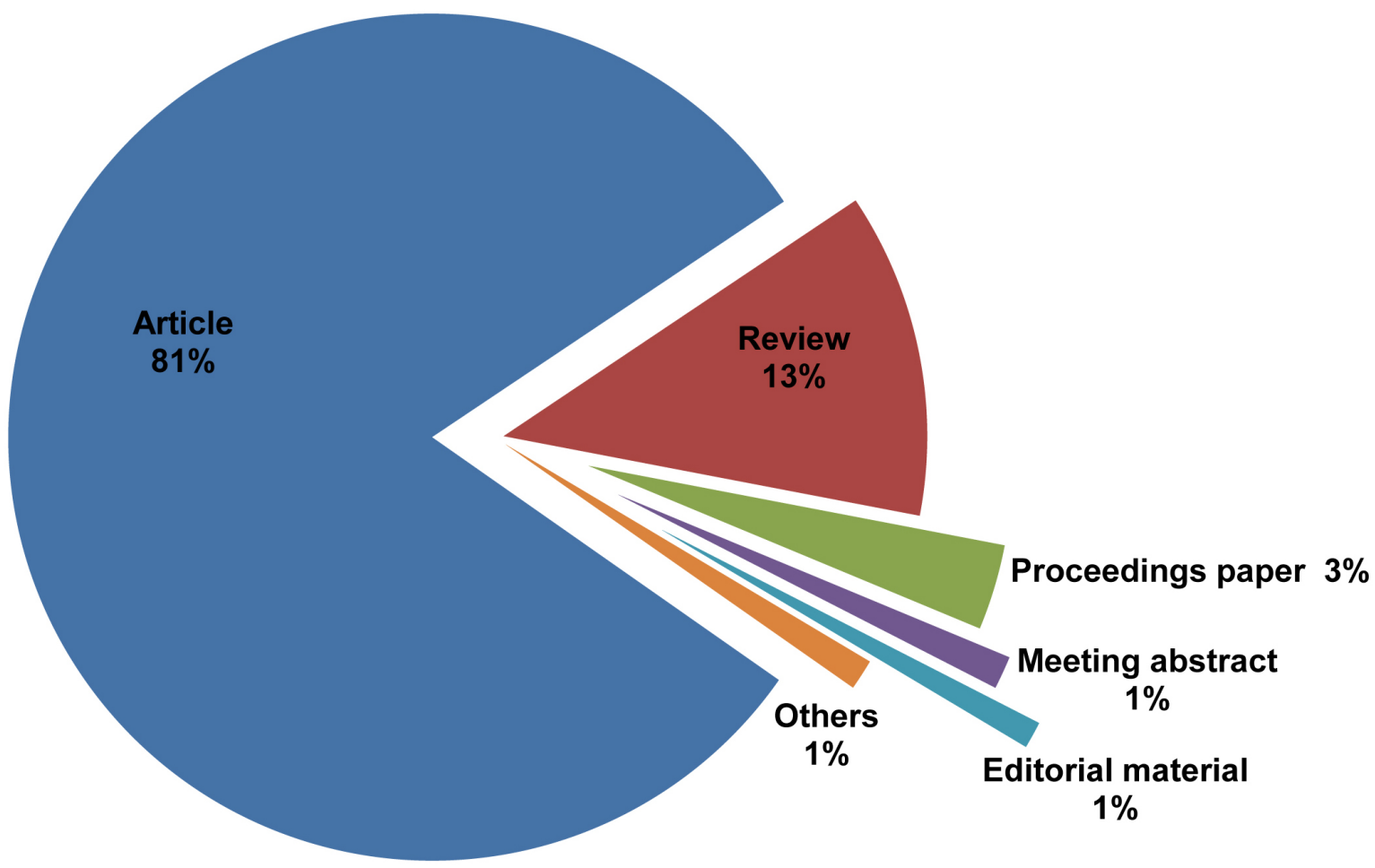

Figure 1. Distribution of publication by document type 

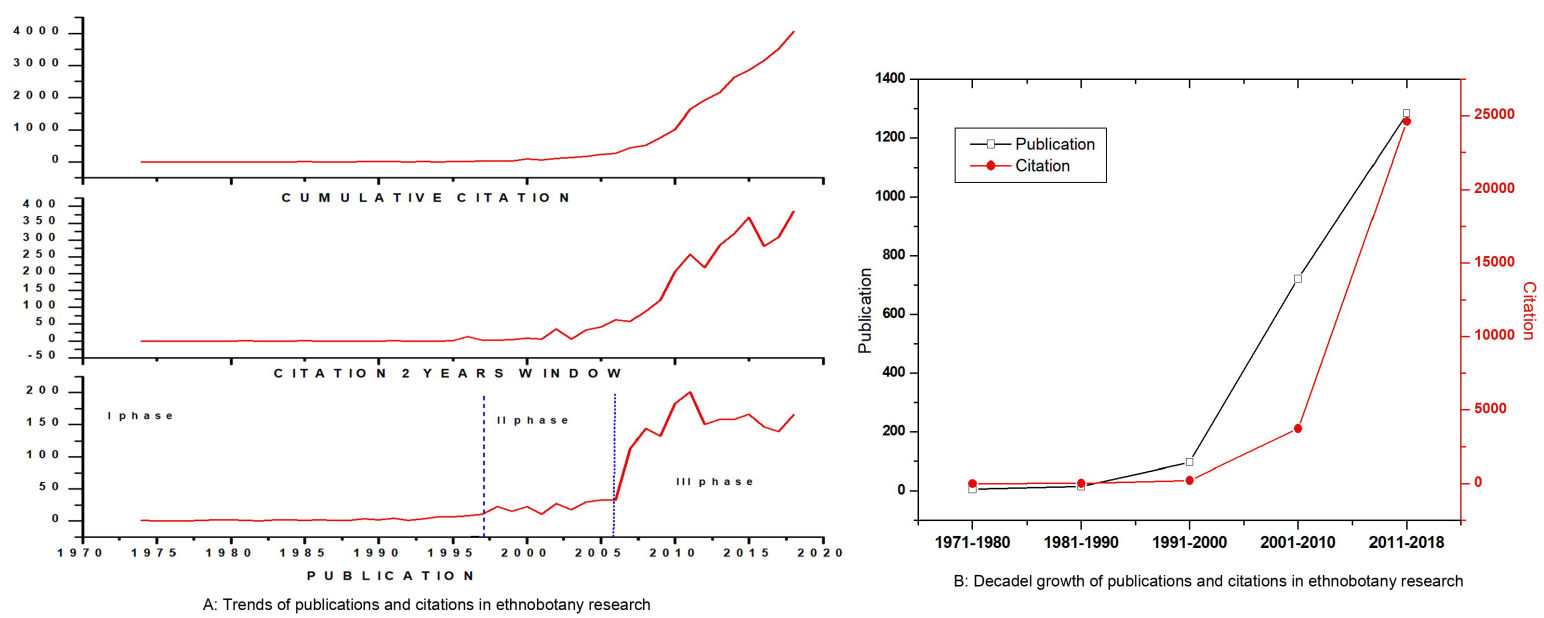

Figure 2. Trends of publication in ethnobotany

It was observed that in between 1975-77 and in 1982 there was zero publication on ethnobotany in $\mathrm{SCl}$ journals. The quantum jump in third phase is due to inclusion of an Indian journal (i.e. Indian Journal of Traditional Knowledge) in the SCl databases in 2007 (Pathak \& Bharati 2018). Table 1 confirms this fact because Indian Journal of Traditional Knowledge is the most preferred journal with 368 (17.33\%) records. However, the oldest journal with highest impact factor is Journal of Ethnopharmacology, but it ranks second amongst the most preferred with 258 $(12.153 \%)$ records. It may be due to the Journal of Ethnopharmacology accepts few articles on traditional ethnobotany, therefore, publication in the journal is little tough. The published research on ethnobotany appeared in 576 periodicals. Of these, top two journals (Indian Journal of Traditional Knowledge and Journal of Ethnopharmacology) shares $29.48 \%$ of the total records and top 10 journals shares $42.53 \%$ of publications (Table 1 ).

Table 1. Ten most preferred journals by Indian authors in Ethnobotany

\begin{tabular}{|l|l|l|l|l|l|l|}
\hline Source Titles & IF & $\mathrm{P}$ & $\mathrm{P}(\%)$ & $\mathrm{C}$ & $\mathrm{C}(\%)$ & $\mathrm{C} / \mathrm{P}$ \\
\hline Indian Journal of Traditional Knowledge & 0.92 & 368 & 17.334 & 2210 & 7.74 & 6.01 \\
\hline Journal of Ethnopharmacology & 3.41 & 258 & 12.153 & 8156 & 28.55 & 31.61 \\
\hline Pharmaceutical Biology & 2.49 & 63 & 2.967 & 702 & 2.46 & 11.14 \\
\hline Current Science & 0.75 & 48 & 2.261 & 994 & 3.48 & 20.71 \\
\hline Journal of Medicinal Plants Research & $\mathrm{NA}$ & 33 & 1.554 & 415 & 1.45 & 12.58 \\
\hline Journal of Ethnobiology and Ethnomedicine & 2.27 & 31 & 1.46 & 1106 & 3.87 & 35.68 \\
\hline Fitoterapia & 2.43 & 28 & 1.319 & 492 & 1.72 & 17.57 \\
\hline Indian Journal of Pharmacology & 1.04 & 26 & 1.225 & 161 & 0.56 & 6.19 \\
\hline Genetic Resources and Crop Evolution & 1.29 & 25 & 1.178 & 107 & 0.37 & 4.28 \\
\hline $\begin{array}{l}\text { Evidence Based Complementary and Alternative } \\
\text { Medicine }\end{array}$ & 1.98 & 23 & 1.083 & 440 & 1.54 & 19.13 \\
\hline
\end{tabular}

Abbreviations: IF, impact factor (JCR 2018), P, publications; C, citations; C/P, average citations

\section{Authorship pattern, productivity and organisations}

It has been observed that publication by single author is $7.63 \%$ only (Fig. 3). Whereas the joint venture was most productive with group of 2 authors with $22.42 \%$ (476 records) share, followed by contributions of three authors $22.14 \%$ (470 records), four authors $17.85 \%$ (379 records), five authors $12.20 \%$ (259 records), etc. Author co-authorship network is prepared in cluster schema of VOSviewer and summarized in Fig. 4. The size of nodes depicts the quantity of contributions by respective authors and edges show the strength of links between the authors. Author co-authorship network identified 354 items, 21 clusters, 1527 links and 1749 total link strength. The top cluster was with 26 items and nine clusters have more than 20 items, it indicates high level of collaboration among authors. 

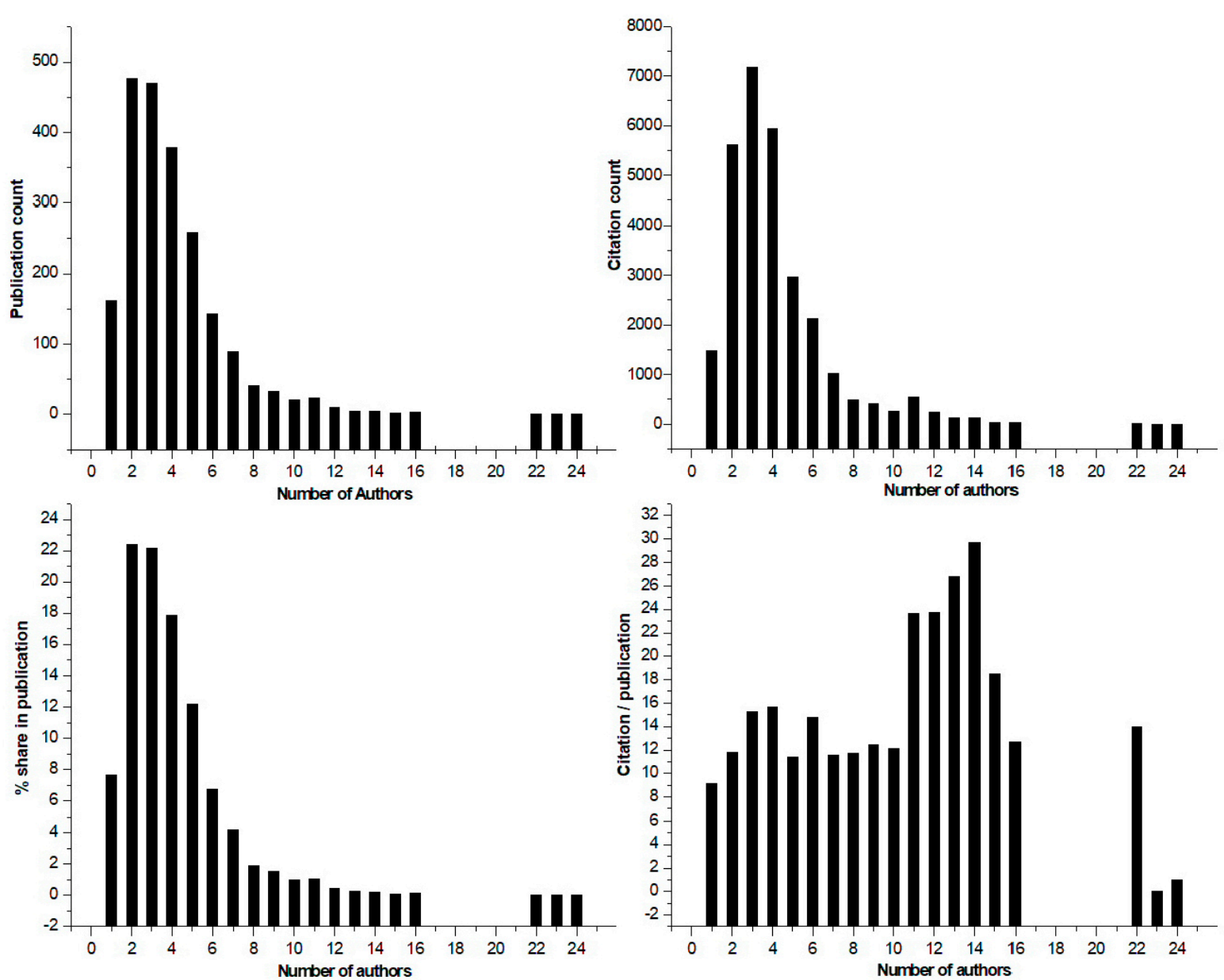

Figure 3. Authorship pattern

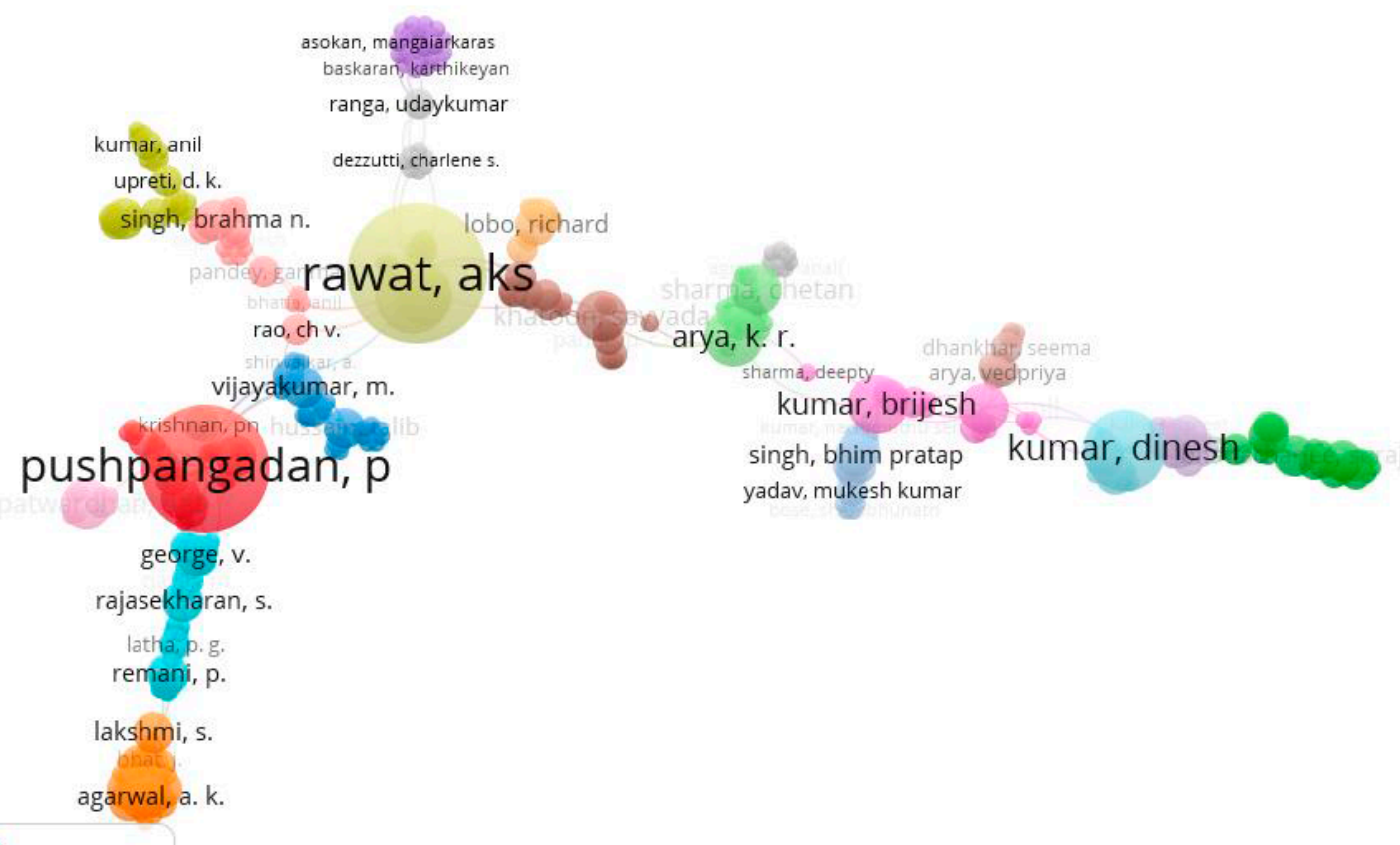

惫 Vosviewer

Figure 4. Author co-authorship network 
A total of 1927 organizations have contributed in publications on ethnobotany. Of these, Council of Scientific \& Industrial Research is the most productive (207 records, 3960 citation) and followed by Indian Council of Agricultural Research (109 records, 824 citations) but both organizations include number of laboratories/institutions. Further, the hindex was highest for Council of Scientific \& Industrial Research (Table 2). Among the CSIR laboratories, National Botanical Research Institute has maximum publications (28) and citations (849). Overall, citations and impact were the highest for Loyola College (1295 citations and 38.09 average citations), it may be due to $\mathrm{S}$. Ignacimuthu (30 records and 1163 citations) and M. Ayyanar (15 records and 584 citations) have been affiliated to this college. Organization network map (Fig. 5) visualized the number of records by respective organizations and link strength between the organizations. There are 63 clusters, 1217 items, 3244 links and 3672 link strength have been identified. The topmost cluster contains 36 items and 54 clusters have more than 10 items, it indicates collaboration among institution is very high though few institutions are involved in the ethnobotany research.

As Fig. 6 revealed, 30 publications are the highest number of papers in India which was produced by two authors namely, S. Ignacimuthu (1163 citations and 38.76 impact) and R.K. Singh (149 citations and 4.96 impact). S. Ignacimuthu has comparatively more citations and better $\mathrm{h}$-index and $\mathrm{p}$-index therefore, he is the most productive author in India. An author productive analysis revealed that 5,458 authors contributed 2123 publications with average 2.57. Contribution by top 15 most productive authors was $11.58 \%$ and majority of the authors $(77.20 \%)$ have published only one record in $\mathrm{SCl}$ journals and $12.47 \%$ of authors have two publications only (Fig. 3 ). Majority of authors have published either one or two records, because a large number of researchers in India are treating ethnobotany research as supplementary research topic.

\section{International collaboration pattern}

In between 1974 to 2018, a total of 1961 collaborative publications appeared on ethnobotany. Domestic collaborations resulted in 1437 papers while international collaboration with 79 countries yielded 524 papers $(24.68 \%)$. Of these, USA was major collaborator with $102(4.8 \%)$ publications, followed by Saudi Arabia 36 (1.6\%), England 28 (1.3 $\%)$, South Korea $26(1.2 \%)$, etc. (Table 3). Fig. 7 shows major collaborating countries, the size of node represent number of records and loops shows collaborations. There are 79 items in 21 clusters with 365 link and 939 link strength, the top three cluster wise countries are as follows:

Cluster 1 (10 countries): Brazil, Canada, Chile, Colombia, Iran, Lebanon, Pakistan, Russia, Spain, Tajikistan.

Cluster 2 (9 countries): Indonesia, Malaysia, Nepal, Peoples R China, Philippines, Singapore, Taiwan, Thailand, Vietnam.

Cluster 3 (8 countries): Australia, Belgium, Bhutan, Germany, Peru, Sri Lanka, Sweden, Tanzania.

\begin{abstract}
Highly cited articles
Publications on Ethnobotany attract relatively less citations than modern disciplines of botany. Keeping this fact in mind, we have studied highly citied articles and summarised top 10 records in Table 4 . The article on anti-diabetic plants by Grover et al. (2002) published in Journal of Ethnopharmacology is on the top in citation analysis with 778 citations. Among the top ten cited records, two are published in domestic journal (i.e. Current Science) and 8 are in foreign journals. Out of eight, four are in Journal of Ethnopharmacology.
\end{abstract}

Table 2. The 10 most productive institutions in ethnobotany research

\begin{tabular}{|l|l|l|l|l|}
\hline Organizations & Records & Citations & Impact & h-index \\
\hline Council of Scientific \& Industrial Research & 207 & 3960 & 19.13 & 32 \\
\hline Indian Council of Agricultural Research & 109 & 824 & 7.56 & 14 \\
\hline Jadavpur University & 54 & 921 & 17.06 & 18 \\
\hline Botanical Survey of India & 40 & 319 & 7.98 & 13 \\
\hline $\begin{array}{l}\text { G B Pant National Institute of Himalayan Environment } \\
\text { Sustainable Development }\end{array}$ & 39 & 726 & 18.62 & 15 \\
\hline North Eastern Hill University & 38 & 323 & 8.50 & 11 \\
\hline Indian Institute of Technology System & 36 & 972 & 27.00 & 15 \\
\hline Jamia Hamdard University & 34 & 376 & 11.06 & 12 \\
\hline Loyola College Chennai & 34 & 1295 & 38.09 & 18 \\
\hline
\end{tabular}




\begin{tabular}{|l|l|l|l|l|}
\hline Assam University & 32 & 202 & 6.31 & 8 \\
\hline
\end{tabular}

\& Vosviewer kisan pg coll
manipal universal learning gulbarga univ
maharaja sayajirao univ baroda avc coll autonomous maharaja sayajirao univ baroda avc coll autonomous ms swaminathan res fdn al ameen coll pharm br nahata coll pharm panjab univ dept bot loyola coll hamdard univ al shifa coll pharm
nbpgr csir sri venkateswara univ
jadavpur univ univ pune hriday
univ calcutta karnatak univ
univ agr sci kumaun univ orissa univ
ashoka trust res ecol \& enviro cnr selcuk univ univ kalyani univ rajasthan pushpawati singhania res inst $\mathrm{ml}$ sukhadia univ dr harisingh cour vishwavidyal inst appl dermatol cent marine fisheries res inst mohanlal sukhadia univ govt arts coll autonomous manipal univ dr mgr univ jiwaji univ father muller med coll himalaya drug co avvm sri pushpam coll autonomo

Figure 5. Collaboration network of organisations

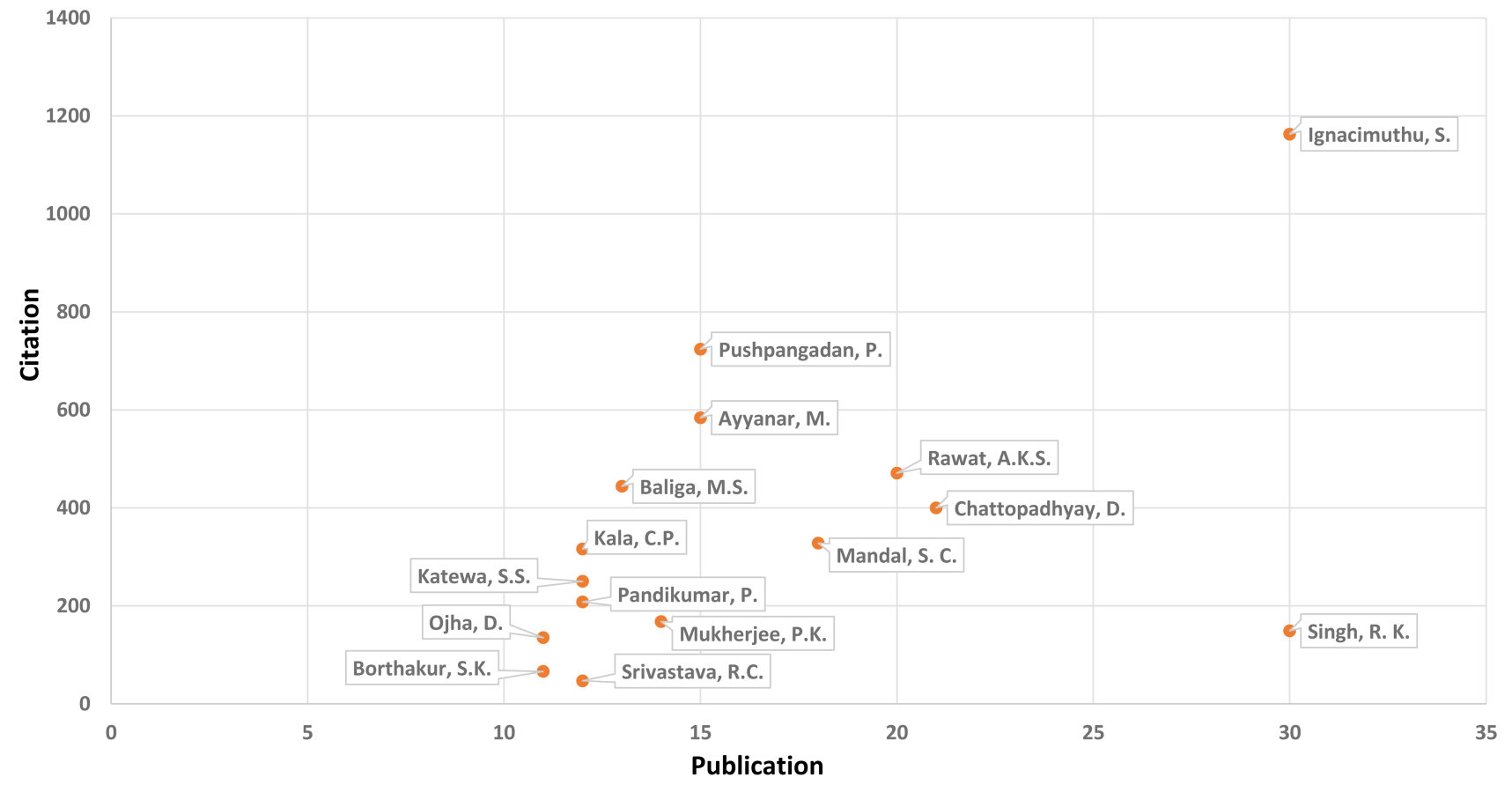

Figure 6. Top 15 most productive authors 


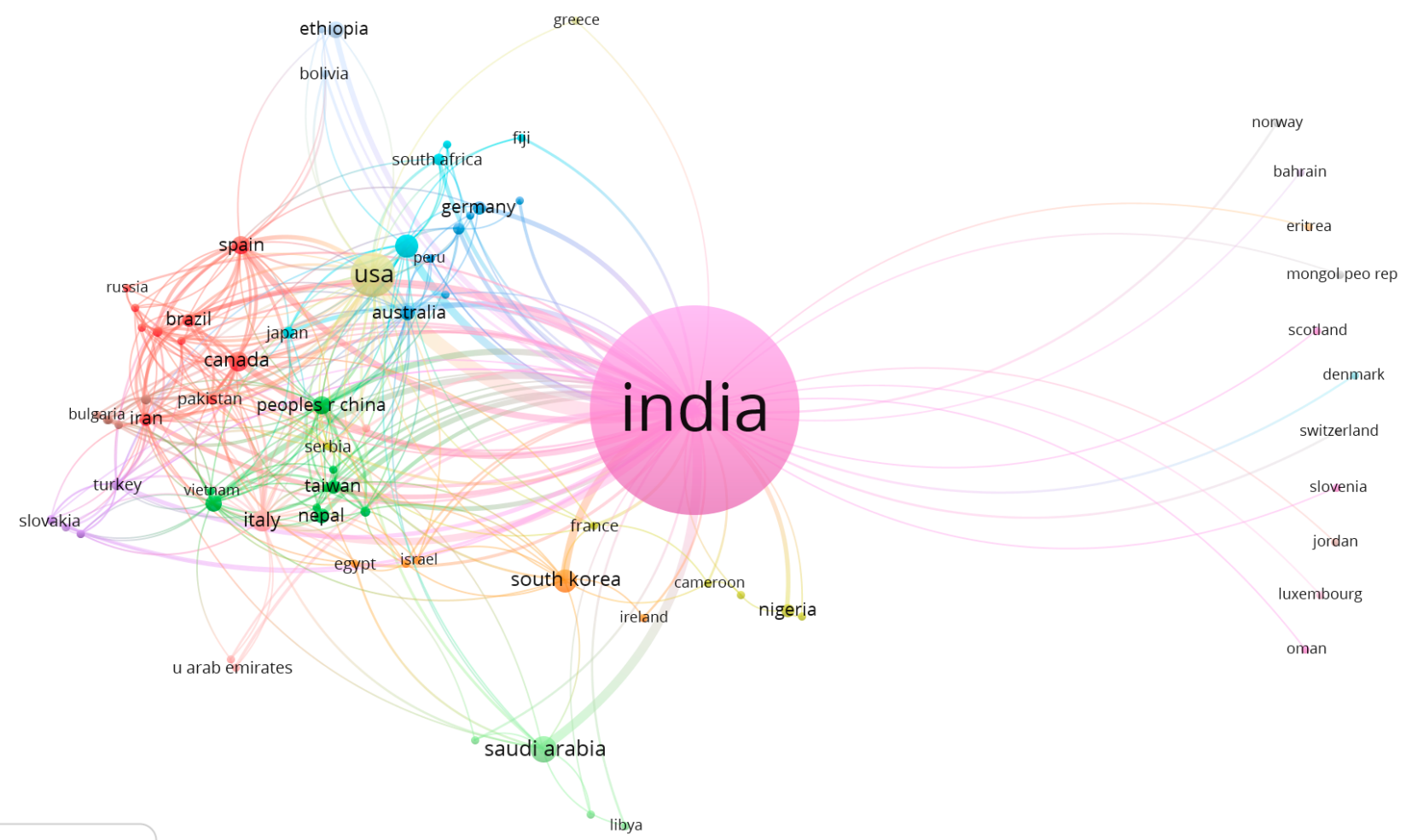

VOSviewer

Figure 7. Collaboration network of India

Table 3. Major international collaborations with India in Ethnobotany research

\begin{tabular}{|l|l|l|}
\hline Country & Record & \% age \\
\hline USA & 102 & 4.805 \\
\hline Saudi Arabia & 36 & 1.696 \\
\hline England & 28 & 1.319 \\
\hline South Korea & 26 & 1.225 \\
\hline Italy & 22 & 1.036 \\
\hline Canada & 20 & 0.942 \\
\hline Spain & 17 & 0.801 \\
\hline Peoples R China & 16 & 0.754 \\
\hline Malaysia & 15 & 0.707 \\
\hline Australia & 13 & 0.612 \\
\hline Ethiopia & 13 & 0.612 \\
\hline Nepal & 12 & 0.565 \\
\hline Germany & 11 & 0.518 \\
\hline Brazil & 10 & 0.471 \\
\hline Taiwan & 10 & 0.471 \\
\hline
\end{tabular}

\section{Most studied tribes of India}

The analysis demonstrated that publications are available on 105 tribes of India. Most studied tribe is Adi of Arunachal Pradesh (17 publications), followed by Kani tribe living in western Ghats of Kerala (14 publications), Malayaii of Kerala (12 publications), Monpa of Arunachal Pradesh (11 publications), Korku of Madhya Pradesh (9 publications), Tharu tribes living on Indo-Nepal boarder areas (8 publications), Naga of Nagaland and Manipur (7 publications), Gond tribe living in many parts of India (6 publications), Bhotia of Himalayan Belt, Garo of Meghalaya, Gujjar living in many parts of Northern India, Jaunsari of Uttarakhand, Paliyar living in southern Western Ghat (5 publications each), etc (Fig. 8). 
Table 4. Top 10 highly cited article in ethnobotany research in India

\begin{tabular}{|c|c|c|c|c|}
\hline Title & Authors & Source Title & $\begin{array}{l}\text { Publicatio } \\
\text { n Year }\end{array}$ & $\begin{array}{l}\text { Total } \\
\text { Citations }\end{array}$ \\
\hline $\begin{array}{l}\text { Medicinal plants of India } \\
\text { with anti-diabetic potential }\end{array}$ & $\begin{array}{l}\text { Grover, JK; Yadav, } \\
\text { S; Vats, V }\end{array}$ & $\begin{array}{l}\text { Journal of } \\
\text { Ethnopharmacology, } 81 \text { (1): } \\
81-100\end{array}$ & 2002 & 778 \\
\hline $\begin{array}{l}\text { Ayurveda and traditional } \\
\text { Chinese medicine: A } \\
\text { comparative overview }\end{array}$ & $\begin{array}{l}\text { Patwardhan, B; } \\
\text { Warude, D; } \\
\text { Pushpangadan, P; } \\
\text { Bhatt, N }\end{array}$ & $\begin{array}{l}\text { Evidence-Based } \\
\text { Complementary and } \\
\text { Alternative Medicine, 2(4): } \\
465-473\end{array}$ & 2005 & 246 \\
\hline $\begin{array}{l}\text { Medicinal plants used by } \\
\text { traditional healers in } \\
\text { Kancheepuram District of } \\
\text { Tamil Nadu, India }\end{array}$ & $\begin{array}{l}\text { Muthu, Chellaiah; } \\
\text { Ayyanar, } \\
\text { Muniappan; Raja, } \\
\text { Nagappan; } \\
\text { Ignacimuthu, } \\
\text { Savarimuthu }\end{array}$ & $\begin{array}{l}\text { Journal of Ethnobiology and } \\
\text { Ethnomedicine, } 2\end{array}$ & 2006 & 209 \\
\hline Herbal medicine & Kamboj, VP & Current Science, 78(1): 35-39 & 2000 & 202 \\
\hline $\begin{array}{l}\text { Ayurveda and natural } \\
\text { products drug discovery }\end{array}$ & $\begin{array}{l}\text { Patwardhan, B; } \\
\text { Vaidya, ADB; } \\
\text { Chorghade, M }\end{array}$ & $\begin{array}{l}\text { Current Science, 86(6):789- } \\
799\end{array}$ & 2004 & 174 \\
\hline $\begin{array}{l}\text { Ethnopharmacological } \\
\text { approaches to wound } \\
\text { healing-exploring } \\
\text { medicinal plants of India }\end{array}$ & $\begin{array}{l}\text { Kumara, B.; } \\
\text { Vijayakumar, M.; } \\
\text { Govindarajan, R.; } \\
\text { Pushpangadan, P. }\end{array}$ & $\begin{array}{l}\text { Journal of } \\
\text { Ethnopharmacology, 114(2): } \\
\text { 103-113 }\end{array}$ & 2007 & 173 \\
\hline $\begin{array}{l}\text { Indian medicinal herbs as } \\
\text { sources of antioxidants }\end{array}$ & $\begin{array}{l}\text { Ali, Shahin Sharif; } \\
\text { Kasoju, Naresh; } \\
\text { Luthra, Abhinav; } \\
\text { Singh, Angad; } \\
\text { Sharanabasava, } \\
\text { Hallihosur; Sahu, } \\
\text { Abhishek; Bora, } \\
\text { Utpal }\end{array}$ & $\begin{array}{l}\text { Food Research International, } \\
\text { 41(1): } 1-15\end{array}$ & 2008 & 172 \\
\hline $\begin{array}{l}\text { Indian medicinal plants as } \\
\text { a source of } \\
\text { antimycobacterial agents }\end{array}$ & $\begin{array}{l}\text { Gautam, Raju; } \\
\text { Saklani, Arvind; } \\
\text { Jachak, Sanjay M. }\end{array}$ & $\begin{array}{l}\text { Journal of } \\
\text { Ethnopharmacology, 110(2): } \\
200-234\end{array}$ & 2007 & 155 \\
\hline $\begin{array}{l}\text { Medicinal and therapeutic } \\
\text { potential of Sea buckthorn } \\
\text { (Hippophae rhamnoides } \\
\text { L.) }\end{array}$ & $\begin{array}{l}\text { Suryakumar, } \\
\text { Geetha; Gupta, } \\
\text { Asheesh }\end{array}$ & $\begin{array}{l}\text { Journal of } \\
\text { Ethnopharmacology, 138(2): } \\
268-278\end{array}$ & 2011 & 154 \\
\hline $\begin{array}{l}\text { Potential synergism of } \\
\text { natural products in the } \\
\text { treatment of cancer }\end{array}$ & $\begin{array}{l}\text { Hemalswarya, S; } \\
\text { Doble, M }\end{array}$ & $\begin{array}{l}\text { Phytotherapy Research, } 20 \\
\text { (4): } 239-249\end{array}$ & 2006 & 152 \\
\hline
\end{tabular}

\section{Author's keywords analysis and research area}

Subject analysis based on author keywords are summarised in the Fig. 9, it shows 148 clusters, 5128 items, 21307 links and total link strength 22873. The top cluster contains 92 items and there are 49 cluster have identified which possess 50 or more items. Application of bibliometrics to the author's key words is important because it potentially detect trending research topics in past and present (Pesta et al. 2018).

Published ethnobotany research covered 98 research areas identified by Web of Science in $\mathrm{SCl}$ databases. The three most common areas were Plant Sciences (902 records; accounting for $42.45 \%$ of the total), Pharmacology \& Pharmacy (742 records; accounting for $34.95 \%$ of the total) and Integrative \& Complementary Medicine (387 records; accounting for $18.22 \%$ of the total). Together the top three research areas accounting for $95.66 \%$ of publication share, other preferred areas are chemistry (4.52\% records), Science \& Technology (4.47\% records), Agriculture $(4.05 \%$ records), Environmental Sciences \& Ecology (3.53\% records), Biochemistry \& Molecular Biology (3.43\% records), Medical Laboratory Technology (3.2\% records), Biotechnology \& Applied Microbiology (3.2\% records) and Food Science \& Technology $(2.82 \%$ records). 


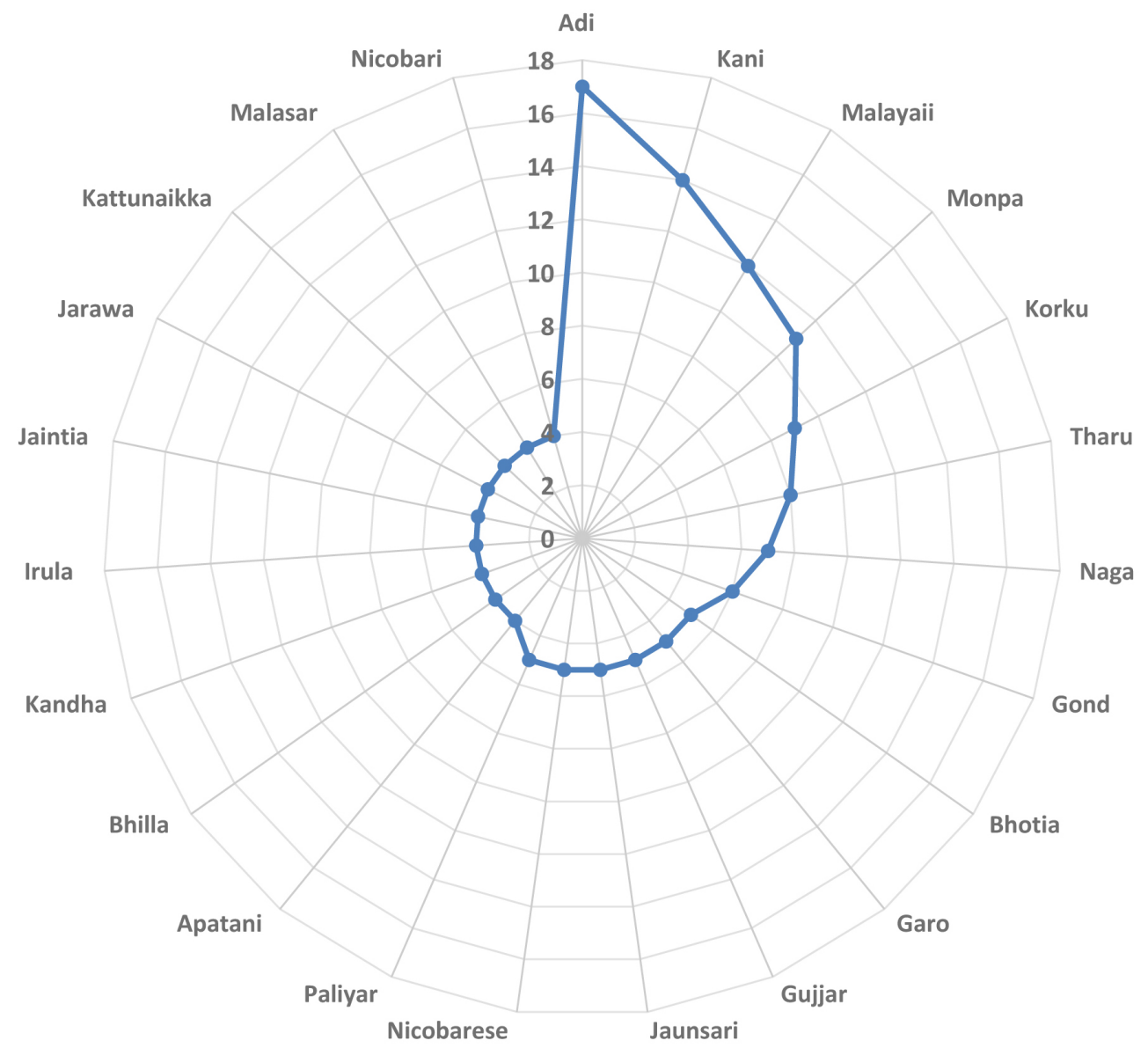

Figure 8. The 22 most studied tribes of India

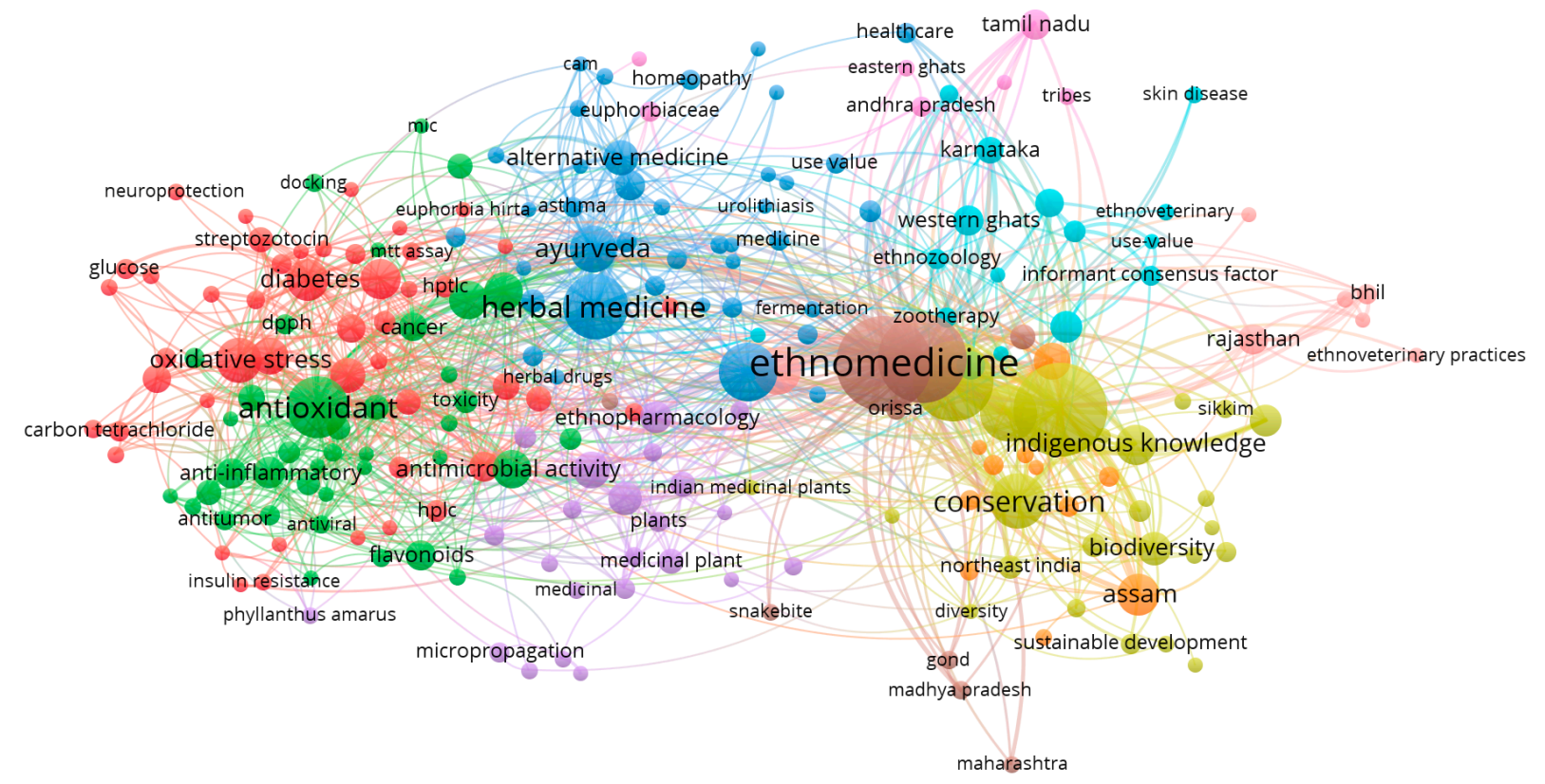

\& VOSviewer

Figure 9. Author key word analysis network 


\section{Conclusions}

The ethnobotany research in India is increasing despite of emergence of new research areas and depletion of traditional knowledge. Since 2007, publications are increasing may be due to the inclusion of Indian Journal of Traditional Knowledge in $\mathrm{SCl}$ databases and overall research grants and strength of researchers have been increased in recent past. A total of 2123 publications have been contributed by 5458 authors were affiliated to 1927 organisations. It indicates that many organisations and large number of researchers were conducted ethnobotanical research. Contrary to our hypothesis big laboratories like Council of Scientific \& Industrial Research and Indian Council of Agricultural Research are the top contributors in ethnobotany research. On the basis of the observations on publication growth, we may speculate exponential growth in the publications on ethnobotany in near future. The present study will provide complementary information to the researchers with a realistic view of the current status of ethnobotany research in India.

\section{Declarations}

This study is limited to research publications indexed in science science-expanded up to year 2018 only.

\section{List of abbreviations: Not Applicable Ethics approval and consent to participate: Not Applicable}

Consent for publication: Not Applicable Availability of data and materials: Data used for this publication is available with the Authors.

Competing interests: No financial and non-financial competing interests.

Funding: No Funding received for this study.

Authors' contributions: Manohar Pathak retrieved the data for the study, KA Bharati drafted the manuscript. Both the authors revised and corrected the manuscript.

\section{Literature cited}

Albuquerque UP, Hurrell JA 2010. Ethnobotany: one concept and many interpretations. In U.P. Edited by Albuquerque de and $\mathrm{N}$ Hanazaki. Recent Developments and Case Studies in Ethnobotany pp. 87-99. Brazil: Brazilian Society of Ethnobiology \& Ethnoecology/Publication Group of Ecology \& Applied Ethnobotany.

Albuquerque UP, Ramos MA, Júnior WSF, De Medeiros, PM. 2017. Ethnobotany for beginners. Springer International Publishing, Switzerland.

Albuquerque UP, Silva JS, Campos JLA, Sousa RS, Silva TC, Alves RRN. 2013. The current status of Ethnobiological research in Latin America: gaps and perspectives. Journal of Ethnobiology and Ethnomedicine, 9:72.

Balick MJ. 1996. Transforming ethnobotany for the new millennium. Annals of the Missouri Botanical Garden 83:58-66.

Barsh RL. 2001. Who steals indigenous knowledge? Proceedings of the ASIL Annual Meeting 95:153161. doi: $10.1017 / S 0272503700056834$.

Bodding PO. 1925. Studies in Santal Medicine and connected folklore-I. Santals and diseases. Memoirs of the Asiatic Society of Bengal 10:1-132.

Bodding PO. 1927. Studies in Santal Medicine and connected folklore-II. Santals medicines. Memoirs of the Asiatic Society of Bengal. 10:133 - 426.

Bodding PO. 1927. Studies in Santal Medicine and connected folklore. Memoirs of the Royal Asiatic Society of Bengal 10:427-502.

Bodding PO. 1983. Santhal Medicine. The Book Trust, Calcutta.

Chakravarthy R. 1975. Watt's Dictionary: A Landmark in the Study of the Economic Plants of India. Economic Botany 29:31-38.

Cox PA. 2000. Will tribal knowledge survive the millennium?. Science 287:44-45.

Dash SS, Pramanik DD, Kumar S, Songh P, Mao AA. 2019. New additions to the India Flora in 2016, Phytotaxonomy 18:1-12.

Dhiman AK. 2000. Ethnobotany Journal: A ten year bibliometric study. IASLIC Bulletin 45:177-182.

Dhiman AK, Sinha SC. 2001. Impact of research collaboration on growth of literature in ethnobotany: A bibliometric study. SRELS Journal of Information Management 8:53-62.

Farnsworth NR, Akerele O, Bingel AS, Soejarto DD, Guo Z. 1985. Medicinal plants in therapy. Bulletin of the world health organization. 63:965.

Gaikwad J, Karen Wilson JK, Subramanyam V, Joanne J, Ranganathan S. 2011. Combining ethnobotany and informatics to discover knowledge from data. Edited by Mahendra R, Acharya D, JL Río. Ethnomedicinal plants: revitalization of traditional knowledge of herbs pp. 444-457. Science Publishers, Enfield, New Hampshire, USA.

Hanazaki N. 2015. Why are we so attached to the "ethno" prefix in Brazil?. Scientometrics 103:545554.

Harborne JB. 2000. Arsenal for survival: secondary plant products. Taxon 49:435-449.

Harshberger JW. 1896. Purposes of ethnobotany. Botanical Gazett. 21:146-154.

Heinrich M. 2000. Ethnobotany and its role in drug development, Phytotherapy Research 14:479-488.

Irwin SJ, Narasimhan D. 2011. Endemic genera of angiosperms in India: a review. Rheedea 21:87-105. 
Jain SK. 1963. Plants used in medicine by tribals of Madhya Pradesh. Bulletin of Regional Research Laboratory 1:126-128.

Kolle SR. 2018. Publication Trends in Indian Journal of Traditional Knowledge: A Bibliometric Analysis. Journal of Advancements in Library Sciences 3:2534.

Myers N, Mittermeier RA, Mittermeier CG, Da Fonseca GA, Kent J. 2000. Biodiversity hotspots for conservation priorities. Nature 403:853.

Pathak M, Bharati KA. 2018. Growing Visibility and Impact of Indian Journal of Traditional Knowledge (2002-2017). Indian Journal of Traditional Knowledge 17:407-413.

Pesta B, Fuerst J, Kirkegaard EO. 2018. Bibliometric Keyword Analysis across Seventeen Years (20002016) of Intelligence Articles. Journal of Intelligence 6:46.

Prance GT. 1991. What is ethnobotany today? Journal of Ethnopharmacology 32:209-216.

Ritter MR, Silva TCD, Araújo EDL, Albuquerque UP. 2015. Bibliometric analysis of ethnobotanical research in Brazil (1988-2013). Acta Botanica Brasilica 29:113-119.

Shah NC. 2008. Ethnobotany in India. Edited by H Selin. Encyclopaedia of the History of Science, Technology, and Medicine in Non-Western Cultures. Springer, Dordrecht.

Shivakumaraswmay KN, Muthuraj TN. 2015. Indian Journal of Traditional Knowledge: A Scientometric Study. International Journal of Library and Information Studies 5:29-41. 